\title{
MCPH1 wt Allele
}

National Cancer Institute

\section{Source}

National Cancer Institute. MCPH1 wt Allele. NCI Thesaurus. Code C114569.

Human MCPH1 wild-type allele is located in the vicinity of 8p23.1 and is approximately

$237 \mathrm{~kb}$ in length. This allele, which encodes microcephalin protein, is involved in both brain development and DNA damage checkpoints. Mutation of the gene is associated with primary, autosomal-recessive microcephaly 1. 